\title{
Detection of Canine Distemper Virus by Surface Plasmon Resonance
}

\author{
C. R. BASSO ${ }^{*}$, J. R. SEMPIONATTO ${ }^{1}$, C. C. TOZATO ${ }^{2}$, J. P. ARAUJO Jr² ${ }^{2}$ G. G. PEREZ ${ }^{1}$ and \\ V. A. PEDROSA ${ }^{1}$ \\ ${ }^{1}$ University Estadual Paulista, Department of Chemistry and Biochemistry \\ ${ }^{2}$ University Estadual Paulista, Department of Microbiology and Immunology \\ E-mail contact: cbasso@ibb.unesp.br
}

\begin{abstract}
A PMMA polymer adsorbed in gold sensor through surface plasmon resonance (SPR) technique was developed for detection the canine distemper virus (CDV) through antibody/antigen binding. The antibodies anti-CDV were physically adsorbed on the surface of the sensor through covalent bonds with the thiol group formed by PMMA/EDC-NHS, the urine samples with the CDV virus were deposited on the sensor to be detected. The highest sensitive sensor surface for urine sample detection was the $200 \mu \mathrm{g} / \mathrm{ml}$ of immobilized in $20 \mu \mathrm{g} / \mathrm{ml}$ of antibodies, with $1 \mu \mathrm{g} / \mathrm{ml}$ of detection limit yielding 50 millidegree of SPR angle shift. After each binding experiment, the sensor surface was completely regenerated prior to the next measurement using $0.2 \mathrm{~mol}$ $\mathrm{L}^{-1}$ glycine- $\mathrm{HCl}(\mathrm{pH} 3)$. All assays were performed in triplicate showing a high efficiency and good reproducibility of the technique.
\end{abstract}

\section{INTRODUCTION}

The canine distemper virus is a highly contagious disease transmitted by virus known as CDV. The transmission of CDV virus occurs through contact the infected animals with healthy dogs, by means of aerosol particles in the air scattered, contact with oral, respiratory and ocular fluids (Basso et al., 2013). This highly contagious disease may or may not follow a logical timeline, but is usually an acute, febrile illness that affects the gastrointestinal system, central nervous system, respiratory system and skin of the animal. The CDV is a pathogen with high rates of mortality, but his eradication is considered impossible because of the virus is wide host range, which includes terrestrial carnivores, but can be preventive operation with vaccination. The high mortality rates of this viral disease necessitate the acceleration of diagnosis procedures to quarantine infected individuals and started the appropriate treatment early (Beineke et al., 2009). Some techniques are used to make the diagnosis of CDV, including indirect fluoroimmunoassay, histopathology, reverse transcription-polymerase chain reaction (RT-qPCR), immunofluorescence, immunohistochemistry and serology, but this techniques has limitations for example: high cost, limits for the diagnosis, time-consuming and a large number of false-positive results (Santos et al., 2009; Wang et al., 2011; Beineke et al., 2009).

Surface Plasmon Resonance (SPR) technique sensing has emerged as a key research tool for pharmaceutical development, food quality control, environmental monitoring and clinical analyses, because this technique can be used to study biomolecular immobilization on gold surfaces including 


\section{9 a 22 de outubro de 2014 \\ Florianópolis/SC}

DNA templates, enzymes, protein, bacteria, cell and biding antigen-antibody.(Scarano et al., 2010). The success of the SPR for biological applications is due to the fact that the technique allows the calculation of the kinetics of biomolecular interactions in real time with a high sensitivity, besides possessing unique characteristics as its high versatility, simplicity, low cost of analysis and detection of compounds of diverse interests, which makes them promising devices for different applications (Carvalho et al., 2003; Chetcutte et al., 1999). The SPR technique can be used to determine kinetic analysis, quantitative analysis, affinities of molecular interactions, comparing different models and species specificity study, but for this to occur the preparation of the surface of the sensor occurs is very important for the proper conduct of research (Pattnaik, 2005). The main objective is to create a support structure for the receptor that ensures stability under working conditions and access to the analyte. The method most commonly used for surface modification is the formation of self-assembled monolayer (SAM). SAM can be formed by thiol-modified biomolecules, RNA and DNA sequences. Another immobilization method involves polymeric species. The polymer properly control to be in the detection range of the evanescent field while maintaining a good uniformity as show by Puttharugsa et al. (2013)

The present work demonstrates the real time binding of CDV an antibody-functionalized through the formation of polymer chain of PMMA active with EDC/NHS. In contrast to the previously mentioned conventional methods for the detection of CDV-specific antibodies, the SPR methodology a convenient means of realizing rapid and sensitive and low cost reagents and samples. Immobilization of the antibody and the formation of antibody-antigen complexes on the $\mathrm{Au}$ film electrode were characterized in detail by SPR. All analyzes were performed in triplicate.

\section{MATERIALS AND METHODS.}

\subsection{Antibodies, positives and negatives samples}

All the antibodies, positives and negatives samples of canine distemper virus was obtained by collecting viral urine samples from animals with histories and clinical signs compatible with distemper. Urine samples from dogs treated in Clinic of Infectious Diseases of Animals Veterinary Hospital, Faculty of Veterinary Medicine and Zootechny UNESP-Botucatu, were from obtained the laboratory for Molecular Diagnostics, Department of Microbiology and Immunology, Institute of Bioscience, UNESP, Botucatu campus. The samples have previously tested positive and negative by RTq-PCR technique.

\subsection{PMMA Polymer preparation}

In a becker on a magnetic an orbital shaker were added $4 \mathrm{ml}$ of methanol $\left(10.14 \mathrm{~mol} \mathrm{~L}^{-1}\right)$, $5 \mathrm{ml}$ methacrylic acid $(0.05 \mathrm{~mol} \mathrm{~L} 1)$ and $1 \mathrm{~mL}$ of deionized water obtained from the Millipore unit, stirred for $10 \mathrm{~min}$. After this step, $1.85 \mathrm{mg}$ of $\mathrm{BrCu}\left(0.013 \mathrm{~mol} \mathrm{~L}^{-1}\right), 12.87 \mathrm{mg}$ of dipyridyl 


\section{9 a 22 de outubro de 2014 \\ Florianópolis/SC}

$\left(0.082 \mathrm{~mol} \mathrm{~L}^{-1}\right)$ and $14.52 \mathrm{mg}$ of ascorbic acid $\left(0.008 \mathrm{~mol} \mathrm{~L}^{-1}\right)$ were added to the becker remained stirring for $5 \mathrm{~min}$. the solution was used immediately.

\subsection{Procedue}

The sensor cleaning was performed by placing it in a beaker with a solution containing industrial detergent and ultrapure water that was brought to ultrasound for $10 \mathrm{~min}$. Then, the disk was washed tree times with ultrapure water. $100 \mu l$ the solution containing phosphate buffer $\mathrm{pH}$ 7.4 (PBS) and Tween $20(0.005 \%)$ was added to the gold electrode surface and remained for $2 \mathrm{~min}$. to create a base line to start measurement. $150 \mu \mathrm{l}$ of the polymer was added to the electrode surface staying for $2 \mathrm{~h}$ to prepare the surface of the gold electrode for adsorption of antibodies, this last time the surface was washed with a solution containing methanol and ultrapure water (2:1) to remove the weakly bound molecules. The terminal carboxylic groups of the linkers were activated with a 50min pulse of a $1: 1$ mixture of $0.4 \mathrm{~mol} \mathrm{~L}^{-1}$ EDC and $0.1 \mathrm{~mol} \mathrm{~L}^{-1} \mathrm{NHS}$ who created the specific binding with amines of the antibodies. Subsequently, the sensor was washed three times with $10 \times 10^{-3} \mathrm{~mol} \mathrm{~L}^{-1} \mathrm{PBS}+0.1 \mathrm{wt} \%$ Tween $20.100 \mathrm{ul}$ of antibody were injected on the sensor surface and maintained for $2 \mathrm{~h}$., washing the sensor was performed PBS + Tween. Four concentrations antibodies were used in this study $(2,6,11$ and $21 \mu \mathrm{g} / \mathrm{ml})$, this concentrations were chosen according to a study by Basso et al. (2013), who obtained better detection antigen using these concentrations. $50 \mu \mathrm{l}$ of $0.1 \times 10^{-3} \mathrm{~mol} \mathrm{~L}^{-1}$ BSA was used as the deactivation solution to block any free non-antigenic binding. Measurements were conducted at room temperature, and the noise level was 1 millidegree. All of the binding analyses using the SPR biosensor were carried out in $10 \times 10^{-3} \mathrm{~mol} \mathrm{~L}^{-1} \mathrm{PBS}+0.1 \mathrm{wt} \%$ Tween $20(0.1 \% \mathrm{PBS}-\mathrm{Tween} 20)$ at $25^{\circ} \mathrm{C}$. In addition to quantitative analysis, kinetic analysis was performed using these data, and affinity constants were calculated using kinetics software. Four concentrations of urine was utilized (4, 60, 100 and $200 \mu \mathrm{g} / \mathrm{ml}$ ) this concentrations were chosen according to a study by Basso et al. (2013), who obtained better detection of virus with this concentrations, $80 \mu 1$ the urine solution were deposited on the surface of the gold electrode during 30min. to bind to antibodies present. After each binding experiment, the sensor disc surface was completely regenerated prior to the next measurement using $0.2 \mathrm{~mol} \mathrm{~L}^{-1}$ glycine- $\mathrm{HCl}(\mathrm{pH} \mathrm{3})$, All products were purchased from SignaAldrich and the samples were previously tested by reverse transcription-PCR (RT-PCR) following the procedure reported elsewhere.

\section{RESULTS AND DISCUSSION}

\subsection{SPR Graphic for Detecting Antibody, Positive and Negative samples}

The adsorption process and the affinity antibody binding for the antigen, is a remarkable change in the curve generated by SPR. In the Figure 1 is showed the process that occurs on the sensor surface. The adsorption of the surface of the polymer is represented by the black line which is activated through the thiol group of the EDC/NHS creating self-assembled monolayers, represented by the red line. The adsorption antibody is represented by the green line, where the 
curve over a displacement increasing its angle compared to the red line, this shift in the SPR angle represent the adsorption of antibody on the sensor surface, the blocking nonspecific sites on the antibodies is represented by pink line through of BSA. The adsorption of antigen CDV is represented by blue line where it is possible to note that there was not displacement when compared to pink line, this result indicates that the sample is positive for specific binding occurred with the antibody, if the sample was negative, change the blue line would more than offset the pink line because it would not occur to antigen/antibody binding. This result can be compared to that obtained by Puttharugsa et al. (2013), where they studied the adsorption of the $A a c$ antigen on the sensor surface and the registered the binding with the specific antibody MAb 10B2 through the SPR technique.

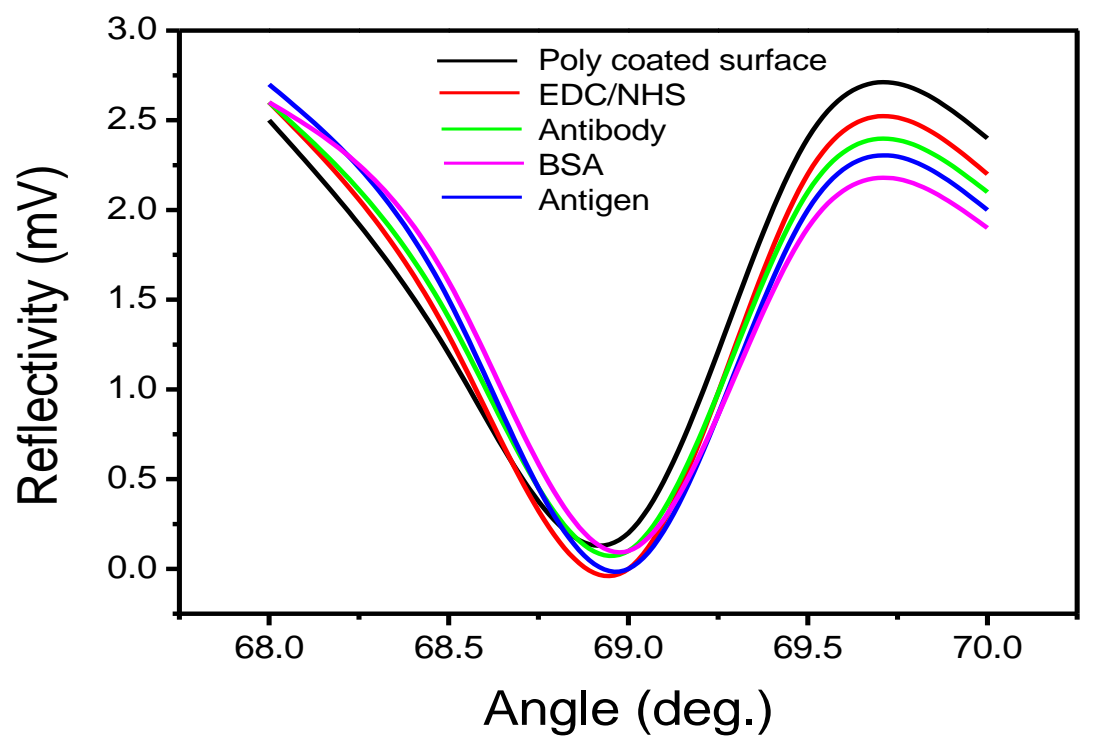

Figure 1- SPR curve of the displacement showing the process of adsorption of the CDV virus

The graph generated by SPR that is shown in Fig. 2 illustrates all the process of modification in sensor surface. Firstly, PBS buffer was added to the surface to form a baseline. The formation of a baseline at the beginning of the experiment is of utmost importance to keep a parameter as reported in the work of Carvalho et al. (2003) where, according to the position of the base line, it is possible to estimate the amount of material adsorbed on the electrode surface and if the samples are positive or negative. At point A, the polymer solution was added, forming SAMs. A solution containing deionizer water and methanol (2:1) was passed at the electrode surface to remove weakly bound molecules (point B). EDC/NHS was dribbled out onto the surface, creating irreversible binding with amines found in antibodies (point $\mathrm{C}$ ) according described by Green et al. (2000). PBS buffer solution plus Tween was passed 3 times on the electrode surface to remove weakly bound material (points D, F, H, J, L, N, P, R, T, V, X and Z). The point $\mathrm{E}$ is added to the anti-CDV so that binds an irreversible way SAMs. A reduction in 


\section{9 a 22 de outubro de 2014 \\ Florianópolis/SC}

signal SPR was observed (points E to F) because of the detachment of some uncoupled not adsorbed, leaving only antibodies strongly connected. Comparing these data with previous studies by (Lee et al., 2013; Franco et al., 2013; Peluso et al., 2013), is confirmed affinity binding and irreversible adsorption of the antibody on the sensor surface, BSA is necessary to block the rest of the electrode surface, thereby preventing non-specific binding (point G). In Point I, the first positive urine sample with concentration $200 \mu \mathrm{g} / \mathrm{ml}$ was added on the surface, where the total quantity of antigen immobilized on the electrode surface was estimated from the difference of SPR angle generated between points I and J, the value of the resonant unit (RU) measured by SPR was 496.6 millidegree. This result shows with occurred adsorption CDV virus in active sites of antibodies and that this is a specific binding. This result was also confirmed by the study of Puttharugsa et al. (2013) in which he can detect through the SPR technique binding between Acidovoraxavenaecitrulli antigen and its specific antibody MAb 10B2. The regeneration of the electrode surface was obtained by passing glycine- $\mathrm{HCl}$ according to the work of Basso et al. (2013) this removed the surface antigen remained intact until the whole structure BSA (points $\mathrm{K}, \mathrm{O}, \mathrm{S}$ and $\mathrm{W}$ ). The second positive urine sample at a concentration of $110 \mu \mathrm{g} / \mathrm{ml}$ was added, the difference in the angle of the point $\mathrm{M}$ to point $\mathrm{O}$ showed the adsorption of 168.3millidegree. The third positive urine sample, concentration $60 \mu \mathrm{g} / \mathrm{ml}$ dripped onto the electrode surface, it is possible to notice a small shift in the SPR angle (points Q to R) in order 104.9 millidegree. The last positive sample adsorbed on the electrode, the concentration of $5 \mu \mathrm{g} / \mathrm{ml}$, showed a change in the angle of 13.03 millidegree almost imperceptible, leading us to the conclusion that this concentration is not possible to obtain a precise and correct result of the analyte (points $\mathrm{U}$ to $\mathrm{V}$ ). Finally, negative control sample a concentration of $110 \mu \mathrm{l} / \mathrm{ml}$ was added in the sensor surface, should be noted that the finish baseline obtained by washing with PBS plus Tween buffer was equal to the baseline before the adsorption of urine sample (point $\mathrm{Y}$ to $\mathrm{Z}$ ), where the change in SPR angle was zero between buffer and urine.

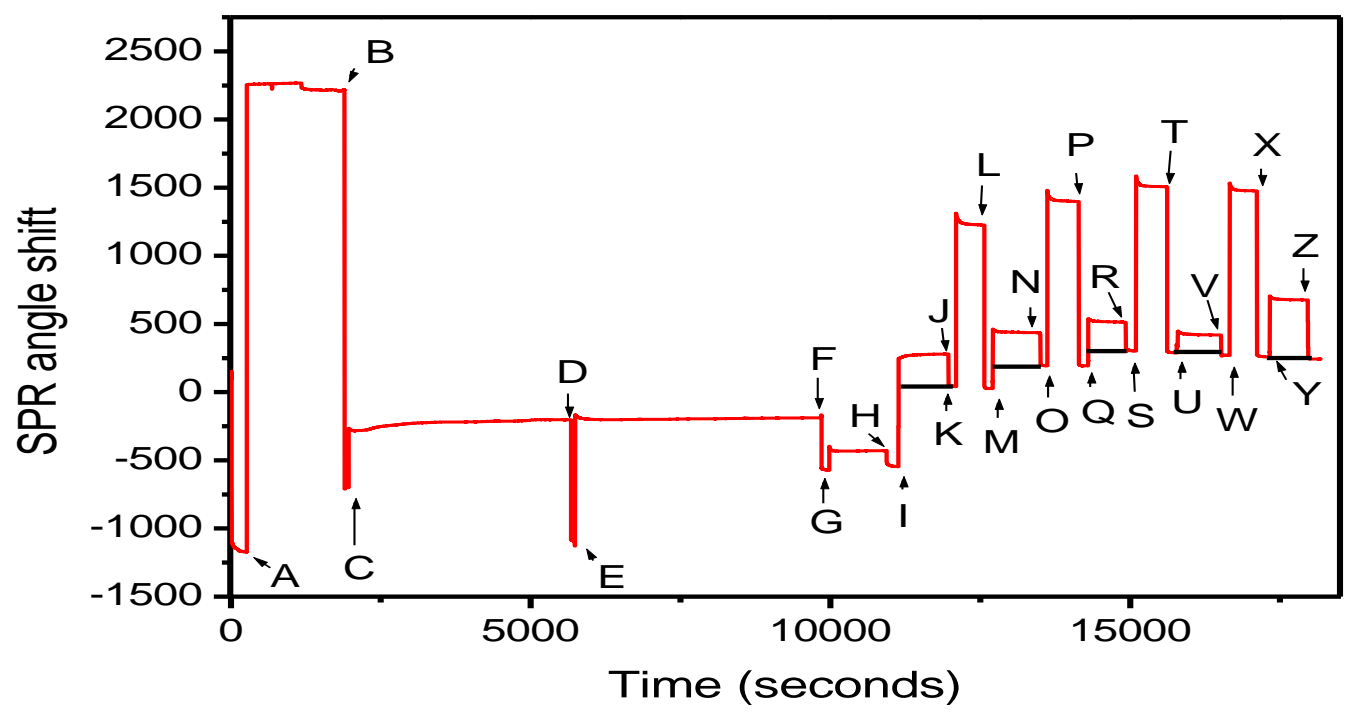

Figure 2- SPR sensorgram showing all steps of modifications in the sensor surface to immobilization of antibodies and antigen detection 


\subsection{Immobilization of Non-Active Sites and Quantification of Urine Samples}

Due to the unoccupied space on the sensor surface, it is necessary to prevent the non-specific binding from the other biomolecules adsorbed directly on the surface (Campbell and Kimb, 2007). The blocking of non-active sites was performed using BSA to block possible nonspecific binding according to a study by Basso et al. (2013) who demonstrated the using the BSA on surface of the sensor is completely filled causing the antigen binds only to exposed sites of the antibodies and prevented from occurring false-positive result. In the Figure 3 is shown throughout the process blocking of the sensor surface, $50 \mu \mathrm{l}$ of $0.1 \times 10^{-3} \mathrm{~mol} \mathrm{~L}^{-1}$ BSA was injected through the sensor surface and followed by PBS buffer, the angle shift around 570 millidegree was observed after the excess the BSA was leached out. $80 \mu \mathrm{l} / \mathrm{ml}$ of urine sample positive was passed over the blocked surface, the excess of the sample was removed with PBS buffer and the baseline obtained was equal to the initial baseline urine sample. This indicates that BSA can be used as the blocking molecule to prevent nonspecific binding on the antibody surface.

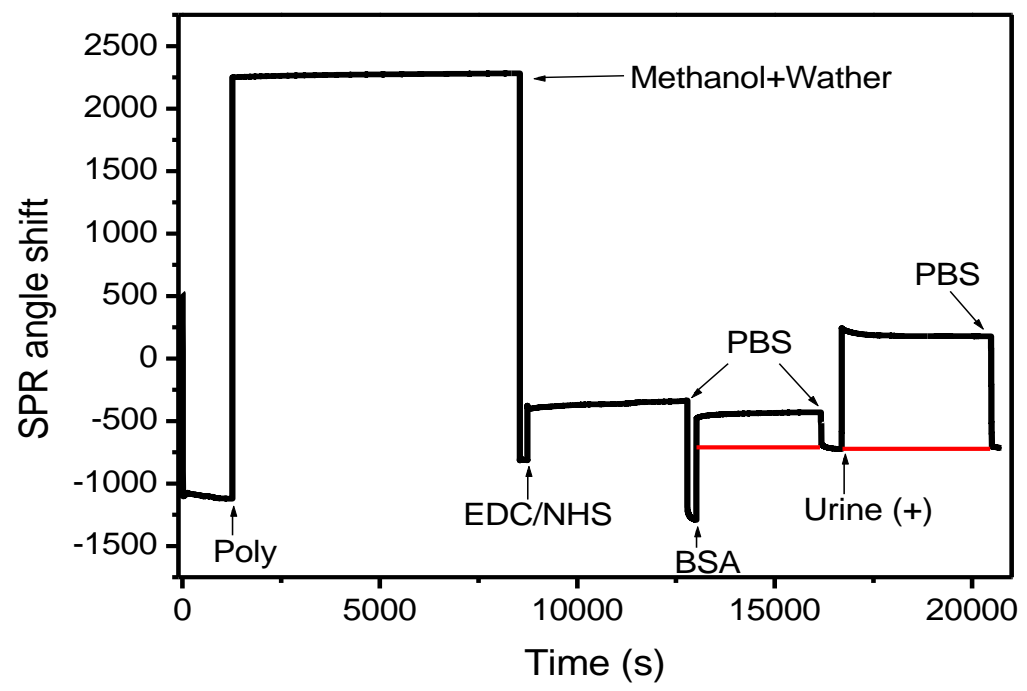

Figure 3- SPR sensorgram shows the adsorbed BSA on the sensor durface to test non-specific binding from CDV virus.

The checking the efficiency of antigen/antibody binding was performed by adsorption of different concentrations of urine samples in different concentrations of antibodies adsorbed on the surface of the sensor, as demonstrated in Figure 4. As expected, the higher immobilized CDV when there was used a more concentrated urine sample in a larger amount of antibodies adsorbed on the surface. The highest sensitive sensor surface for urine sample detection was the $200 \mu \mathrm{g} / \mathrm{ml}$ of immobilized in $20 \mu \mathrm{g} / \mathrm{ml}$ of antibodies, with $1 \mu \mathrm{g} / \mathrm{ml}$ of detection limit yielding 50 millidegree of SPR angle shift. Comparing the immobilization of $100 \mu \mathrm{g} / \mathrm{ml}$ urine sample with the immobilization of $200 \mu \mathrm{g} / \mathrm{ml}$ which was 912 millidegree for $200 \mu \mathrm{l} / \mathrm{ml}$ and 716 millidegree for $100 \mu \mathrm{l} / \mathrm{ml}$, it is noted that the sensitivity connection with the sample $100 \mu \mathrm{l} / \mathrm{ml}$ is lower than containing the sample $200 \mu \mathrm{l} / \mathrm{ml}$, this can be explained by different orientation of the immobilized 
antibody on the surface sensor. With that, the result suggests that the best concentration of CDV antigen to work is $200 \mu \mathrm{g} / \mathrm{ml}$.

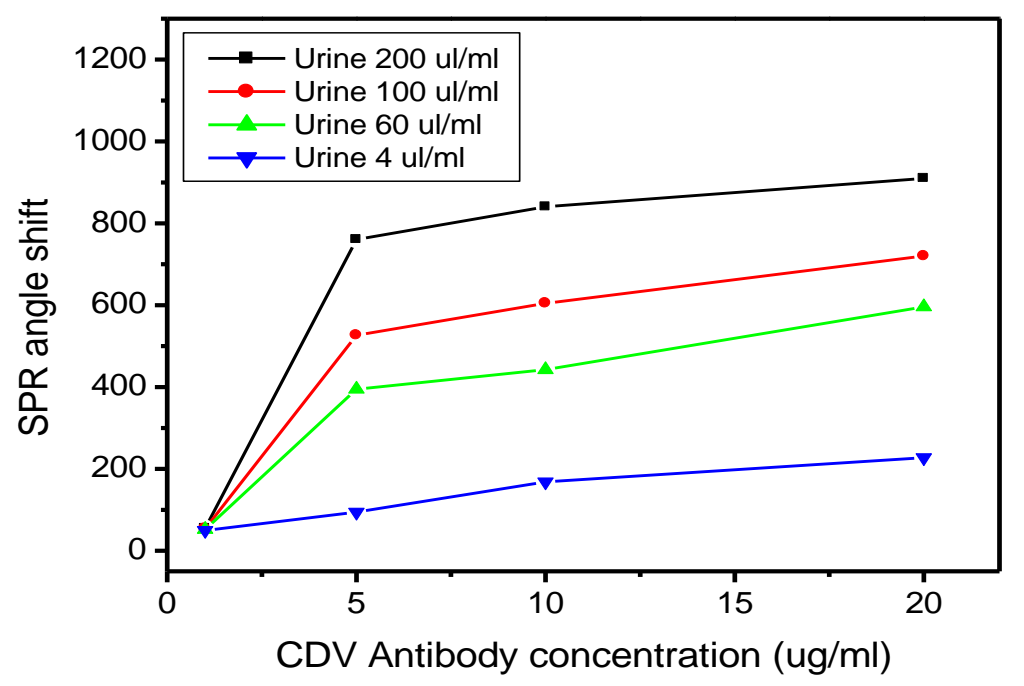

Figure 4- SRP shift the angle of correlating differents concentrations of positive urine samples and antibodies on the sensor surface with PMMA polymer modified.

\section{CONCLUSION}

In this paper, we demonstrate the detection of the canine distemper virus infections in urine samples guided by self-assembled monolayer using PMMA polymer through the technique of surface Plasmon resonance (SPR). The optimal concentration of antigen to achieve found experiments was $200 \mu \mathrm{g} / \mathrm{ml}$ immobilized on the sensor surface containing $20 \mu \mathrm{g} / \mathrm{ml}$ of antibodies with a detection limit of $1 \mu \mathrm{g} / \mathrm{ml}$. Test to block non-specific binding was performed using BSA for inactive sites blocked. The sensor surface may be regenerated after each experiment using 0.2 mol L ${ }^{-1}$ glycine- $-\mathrm{HCl}(\mathrm{pH} 3$ ). In addition, the method will be useful to evaluate the efficacy of antiviral drugs in vivo and in vitro. SPR technique has as its main attributes the selectivity and sensitivity, and when compared to other existing methods the advantages are its simplicity, low consumption of reagents and higher sample frequency.

\section{REFERÊNCIAS}

BASSO, C. R.; TOZATO, C. C.; RIBEIRO, M. C. M.; ARAUJO JUNIOR, J. P.; PEDROSA, V. A. A immunosensor for the diagnosis of canine distemper virus infection using SPR and EIS. Anal. Methods, v. 5, p. 5089-5095, 2013. 
BEINEKE, A.; PUFF, C.; SEEHUSEN, F.; BAUMGARTNER,W. Patogênese e imunopatologia da cinomose sistêmica e nervosa. Vet Immunol. Immunop., v. 127, p. 1-18, 2009.

CAMPBELL, C. T.; KIMB, G. SPR microscopy and its applications to high-throughput analyses of biomolecular binding events and their kinetics. Biomaterials, v. 28, p. 2380, 2007.

CARVALHO, R. M.; RATH, S.; KUBOTA, L. T. SPR-Uma nova ferramenta para biossensores. Rev. Quím. Nova, v. 26, p. 97-104, 2003.

CHETCUTTE, A. F.; WONG, D. K. Y.; STUART, M.C. Anal. Chem., v. 71, p. 4088, 1999.

FRANCO, E. J.; CARUZ, A.; PEDRAJAS, J. R.; LECHUGA, L. M. Site-directed antibody immobilization using a protein A-gold binding domain fusion protein for enhanced SPR Immunosensing. Analyst, v. 138, p 2023-2031, 2013.

GREEN, R. J.; FRAZIER, R. A.; SHAKESHEFF, K.M.; DAVIES, M. C.; ROBERTS, C. J.; TENDLER, S.J. B. Surface plasmon resonance analysis of dynamic biological interactions with biomaterials. Biomaterials, v. 21, p. 1823-1835, 2000.

LEE, J. E.; SEO, J. H.; KIM, C. S.; KWON, Y.; HA, J. H.; CHOI, S. S.; CHA, H. J. A comparative study on antibody immobilization strategies onto solid surface. Korean J. Chem. Eng, v. 30, p. 1934-1938, 2013.

PELUSO, P.; WILSON, D. D.; DO, D.; TRAN, H.; VENKATASUBBAIAH, M.; QUINCY, D.; HEIDECKER,B.; POINDEXTER, K.; TOLANI, N.; PHELMAN, M.;WITTE, K.; JUNG, L.S.; WAGNER, P.;NOCK, S. Optimizing antibody immobilization strategies for the construction of protein microarrays. Anal. Biochemistry, v. 312, p. 113-124, 2003.

PUTTHARUGSA， C.; WANGKAM， T.; HOUNGKAMHANG， N.; YODMONGKOL， S.; GAJANANDANA, O.; HIMANANTO, O.; SUTAPUN, B.; AMARIT, R.; SOMBOONKAEW, A.; SRIKHIRIN, T. A polymer surface for antibody detection by using surface Plasmon resonance via immobilized antigen. Curr. Aplied Phys., v. 13, p. 1008-1013, 2013.

SANTOS, N.; ALMENDRA, C.; TAVARES, L. Serologic Survey for Canine Distemper Virus and Canine Parvovirus in Free-ranging Wild Carnivores from Portugal. J. of Wild. Diseases, v. 45, p. 221-226, 2009.

WANG, X.; REAN, L.; TU, Q.; WANG, Y.; ZHANG, M.; LI, M.; LIU, R.; WANG, K. Magnetic protein microbead-aidec indirect fluoroimmunoassay for the determination of canine virus specific antibodies. Biosensens. Bioelectron, v. 26,p. 3353-3360, 2011. 